\section{Artur Malina}

University of Silesia in Katowice

malina@naos.pl

ORCID: 0000-0002-2830-9902

DOI: http://dx.doi.org/10.12775/BPTh.2019.008
Biblica

et

Patristica

Thoruniensia

12 (2019) 2: 143-156

ISSN (print) 1689-5150

ISSN (online) 2450-7059

\title{
"Like the Angels in Heaven" (Mark 12:25). The Significance of Comparison and the Celibacy of the Resurrected
}

\section{„Jak aniołowie w niebiosach" (Mk 12,25). Znaczenie porównania a bezżenność zmartwychwstałych}

\begin{abstract}
The subject of the study is the significance of comparing the resurrected to the angels. Many commentators identify the state of celibacy as their common feature. This explanation is based on some of the texts of Jewish apocalypticism considered as parallel to the answers of Jesus. This interpretation does not accurately render the meaning of the conjunction "but" (á $\lambda \lambda \dot{\alpha})$, which combines the clause depicting the resurrected as unmarried with the other part of the sentence containing this comparison. The sentence introduced by this conjunction does not elaborate or explain the announcement of celibacy because its content is the promise that the resurrected will dwell with God like the angels who are in heaven.
\end{abstract}

Streszczenie. Przedmiotem studium jest znaczenie porównania zmartwychwstałych $\mathrm{z}$ aniołami. Wielu komentatorów identyfikuje stan bezżenności jako ich cechę wspólną. Wyjaśnienie to opiera się na niektórych tekstach apokaliptyki żydowskiej wskazywanych jako paralelne do odpowiedzi Jezusa. Interpretacja ta niedokładnie oddaje znaczenie spójnika „ale” (ả $\lambda \lambda \alpha$ á), który łączy zdanie przedstawiające zmartwychwstałych jako bezżennych ze zdaniem zawierającym to porównanie. Zdanie wprowadzone przez ten spójnik nie uszczegóławia ani nie wyjaśnia zapowiedzi o bezżenności. Jego treścią jest bowiem obietnica przebywania zmartwychwstałych razem z Bogiem na podobieństwo aniołów, którzy są w niebiosach.

Keywords: the Gospel according to St. Mark; eschatology; angelology; the Sadducees.

Słowa kluczowe: Ewangelia Marka; eschatologia; angelologia; saduceusze. 
Jesur esus announces to the Sadducees that after the resurrection men and women will not get married. ${ }^{1}$ Is the comparison of the resurrected to the angels, which follows this announcement, based on the belief in the celibacy of spiritual beings confirmed by the sources of Judaism of that time? An affirmative answer to this question is given by numerous commentaries. Before verifying this approach, it is worth paying attention to the place in the narrative and the function of the announcement containing the comparison from the title of the article.

\section{Announcement with a comparison in the narrative}

At first, Mark presents the actual aim of the Sadducees' intervention when he characterizes them as negating the truth about the resurrection. ${ }^{2}$ Then he quotes their speech. The Sadducees refer to the law recorded in books recog-

1 The use of the passive form of the second verb does not show clearly who is the real subject of the action where the grammatical subject are women. They can be husbands, fathers or brothers (the other reference in the translation of the New International Reader's Version: “... their parents won't give them to be married. They will be like the angels in heaven"). The distinction of sexes expressed by Greek forms of the active voice $\gamma \alpha \mu$ ov $\sigma ı v$

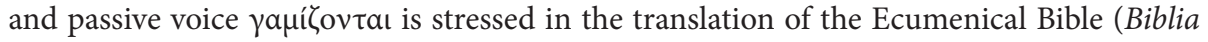
Ekumeniczna) with a participle which is different for the masculine and feminine gender in compound future tense in Polish: "When the dead rise, they will neither marry nor be given in marriage but they will be like the angels in heaven." This distinction does not exist in other Polish translations (the Poznań Bible, St. Paul's Edition, Biblia Warszawsko-Praska or subsequent editions of the Millennium Bible (Biblia Tysiaclecia) which use the structure with the infinitive form. The translation prepared for the Great Jubilee of 2000 by Popowski renders the present tense of the Greek text "they are neither married or given in marriage but are like the angels in heaven." In any case the wording does not give ground to claim that there will not be any difference between men and women in the new creation. (R. Pesch, Das Markusevangelium. II, 233: „Daß man weder heiratet noch geheiratet wird, bedeutet die Aufhebung des Unterschieds von Mann und Frau [vgl. auch Gal 3,27f; 5,6; 6,15] in einer neuen Schöpfung”; P. Dschulnigg, Das Markusevangelium, 320: „Die Unterschiede von Mann und Frau werden in der neue Schöpfung aufgehoben”).

2 An indirect testimony of the rejection of faith in the resurrection by the Sadducees might be the following characteristic of this group given by Flavius Josephus: "They also take away the belief of the immortal duration of the soul, and the punishments and rewards in Hades" (BJ 2, 165), whereas their objection is directly confirmed by the Mishnah: "The Sadducees asked Rabban Gamaliel II if it is possible to prove that the Holy, may His name be blessed, can raise the dead. He answered them: "Yes from the Law, Prophets and Scripts. They, however, did not accept it." (m.Sanh. 90: 2) - quoted after M. Wróbel, Faryzeusze i saduceusze wobec zmartwychwstania, 148-149. 
nized by them as the word of God, so that on the example taken to extremes seven brothers successively marry a woman who at the end also dies - demonstrates the absurdity of faith in the resurrection relying on the necessity to decide whose wife this woman would be. Their question, undermining the faith in the resurrection, only superficially affirms the value of marriage, and, in fact, corresponds to their interests in material benefits.

The law of the levirate was justified mainly by the need to ensure inheritance of land in one family, ${ }^{3}$ as it ordered a single brother of the deceased to marry a widow if there were no male descendants from the first marriage (Dt 15:5-10). In this way, the first-born son from the second marriage, who was given the name of the deceased, was considered a legitimate descendant of the first husband. If one remembers this meaning of the law evoked by the Sadducees, the contrast between the interest of the Sadducees directed to worldly matters and the response of Jesus which goes beyond the earthly order is even more noticeable.

Commentators of the pericope, referring to the announcement about celibacy of the resurrected and its comparison to the state of angels in heaven, quote Paul's teaching about the resurrection of bodies (1 Cor 15:35-53). ${ }^{4} \mathrm{He}$ writes about the life of the resurrected, as different from earthly existence, as the spiritual body ( $\sigma \tilde{\omega} \mu \alpha \pi v \varepsilon v \mu \alpha \tau$ $\psi v x$ ıкóv) (1 Cor 15:44). The apostle develops his teaching on this subject in the form of a diatribe, or rhetorical dialogue, which starts with two parallel questions: "How are the dead raised? With what kind of body do they come" (1 Cor 15:35). ${ }^{5}$ Thus, also on the formal level, the opening of this imaginary conversation - especially through the harsh assessment of the imaginary interlocutor is similar from the beginning to Jesus' answer to the actual contestation of the Sadducees. The Apostle, referring to the imaginary adversary, uses the epithet "fool" (ä $\varphi \rho \omega v)$ (1 Cor 15:36), urging the real addressee of his words to pay special attention to the importance of this teaching.

3 According to Num 27:1-11, the inheritance law passed on to daughters in the absence of male descendants.

4 This explanation is offered, among others, by V. Taylor, The Gospel According to St. Mark, 483; E. Haenchen, Der Weg Jesu, 411; J.R. Edwards, The Gospel According to Mark, 367.

5 The features characteristic of this kind of statement starting from v. 29 are distinguished by the exegetes mentioned by J.R. Asher, Polarity and Change in 1 Corinthians 15, 55 n. 78. 
In the same way, the form of Jesus' response ${ }^{6}$ to his real opponents emphasizes the importance of his teaching in the light of their reference to the authority of Moses in order to undermine the truth of the resurrection. Jesus also accuses them twice, which is similar to Paul's epithet. At first, he accuses them of ignorance and the objection is expressed in the form of a rhetorical question - "Is not this why you are wrong, that you know neither the scriptures nor the power of God?" (Mark 12:24), whereas, at the end, he concludes concisely: "You are quite wrong" (Mark 12:27). ${ }^{7}$ The first accusation is longer because it is to attract interest to the following justification. The content of their error is not an insignificant issue which would concern the nuances of the interpretation of one of many rules, but a matter of fundamental importance for every believing Israelite: the knowledge of the Holy Scriptures and the power of God. Jesus' interlocutors have no idea of the two most important characteristics of Moses' activity, namely his direct knowledge of the Lord and his actions characterized by extraordinary power (Dt 32:10-12). Jesus proves this double lack of knowledge, referring first to the second part - their ignorance of God's power (Mark 12:25), and then to the first one - ignorance of the Scriptures (Mark 12:26). The objection formulated at the end is very short, as it is to be a conclusion, which obviously results from the two-part justification of His accusation of their double ignorance. ${ }^{8}$

6 In the next pericope, the Evangelist introduces the statement of the scribe as a question, and the words of Jesus are simply a response. It is the questioning scribe who accepts His argumentation for the resurrection as a good answer: "seeing that he answered them

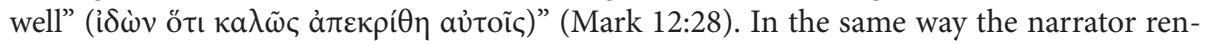
ders all views of His opponents on the third day of Jesus' public activity in the temple: "no one dared to ask him [any question]" (Mark 12:34). In the accounts of the Sadducees alone, the words of Jesus are not introduced as an answer to their question (as in Matt 22:29, even though their words are presented by Mark as a question: "asked him a question" ( $\dot{\varepsilon} \pi \eta \omega \dot{\tau} \tau \omega v$ aủंóv) Mark 12:18). Their statement contains one question about the marriage of a seven-fold widow if she and her husbands were resurrected. This form of their statement is significant in relation to other issues raised by Jesus' opponents. Their main problem, the coherence of the doctrine on resurrection, is not presented as a question to be solved, but as a teaching to reject using an imaginary example. In other words, they do not ask two questions - one about the resurrection and the other about the marriage of the seven-fold widow, but only one about the marriage after the resurrection. On two questions of the Sadducees, at the beginning and at the end of the conversation with Jesus, see, among others, S. Grasso, Vangelo di Marco, 283.

7 In the Greek text there are two words only. The content of the objection is strengthened by the alliteration of these short words: $\pi 0 \lambda \dot{v} \pi \lambda \alpha v \tilde{a} \sigma \theta \varepsilon$.

8 The chiastic structure clearly refers the two-part justification to the double accusation. The chiastic structure is presented by B. Standaert, Marco, 640 (also G. Perego, Vangelo secondo Marco, 251-252): 


\section{Dominant interpretations in commentaries}

Some commentators link the answer with more general statements which can be found in the ancient sources of Judaism from the Second Temple period and in the rabbinical writings about the similarity of the existence of the righteous to the existence of angels in the world to come:" "You are about to be making a great rejoicing like the angels of heaven" (HenEt 104, 4; cf. also HenEt 39, $4-8 ; 51,4 ; 104,6) ;$ "... then both these and those will be changed, these into the splendor of angels ... For they will live in the heights of that world and they will be like the angels and be equal to the stars" (ApBaSyr 51, 5. 10) ${ }^{10}$; "You shall be like an angel of the face in the holy residence for the glory of the God of Hosts ... sharing the lot with the angels of the face"(1Q28b 4,24-26)."11 A general comparison is also present in the letter on the Martyrdom of St. Polycarp: "They were no longer men, but had already become angels" (Mart.Pol. 2, 3). ${ }^{12}$ Although according to the Babylonian Talmud the difference between "this world" and "the world to come" is based on the termination of reproduction and procreation: "The world to come is not like this world; in the world to come there is neither reproduction nor procreation" (b.Ber. 17a). ${ }^{13}$ However, these texts, like the aforementioned fragment of Paul's teaching from the First Letter to the Corinthians, do not refer this similarity to the celibacy of angels.

The prepositional phrase "in heaven" used in the Gospel can be treated as an attribute to differentiate between the angels in heaven and another category which appears in Jewish apocalypticism interpreting the mysterious text from

a) ov่... $\pi \lambda \alpha v \tilde{a} \sigma \theta \varepsilon$

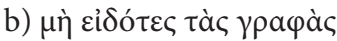

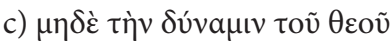

c') evidence from God's power ( $\dot{\omega} \varsigma$ ă $\gamma \gamma \varepsilon \lambda \circ \mathrm{o})$

b’) evidence from Scripture (oủk ảvé $\gamma \nu \omega \tau \varepsilon$ )

a) $\pi \mathrm{o} \lambda \dot{v} \pi \lambda a v a \tilde{\sigma} \sigma \varepsilon$.

9 Cf. E. Lohmeyer, Das Evangelium des Markus, 256 n. 6; R.H. Gundry, Mark, 707; C.A. Evans, Mark 8:27-16,20, Nashville 2001, 255; M.E. Boring, Mark, 340; D. Bock, Mark, 310.

10 This and following translations: The Old Testament Pseudoepigrapha, vol. 1-2, ed. J.H. Charlesworth, New York 1983-1985.

11 Translated after F.G. Martínez, The Dead Sea Scrolls Translated, 433. Cf. also: 1QS 11, 8; 1QH 11, 21-23; 14, 13; 19, 13.

12 Translated after K. Lake, The Apostolic Fathers, v. 2, 315.

13 Translated after Y. Kiel, Sexuality in the Babylonian Talmud, 62 n. 49. 
the beginning of the sixth chapter of the Book of Genesis. This meaning is confirmed by the variants from more numerous but also later manuscripts, which relate to the presence of the article in the expression "angels in heaven." 14

Numerous commentaries, ${ }^{15}$ including the leading ones in the Polish language, ${ }^{16}$ directing attention to other testimonies of Judaism, combine the celibacy of the resurrected with the same state of angels. The celibacy of the latter was to be associated with their calling to existence in heaven. Thus the Ethiopian Book of Enoch mentions three times angels who left heaven to mate with women.

The first text is an extension of the enigmatic biblical text about the sons of God who mate with the daughters of men (Gen 6:1-4). ${ }^{17}$ Angels named the sons of heaven are depicted as male beings. ${ }^{18}$ First, they decide to stay with women called daughters of humans and had children by them. After swearing

14 An article before the word oủ pavoĩ is confirmed by all manuscripts. Many of them add the article oi before the noun ä $\gamma \gamma \varepsilon \lambda$ o $(W, 892)$, before the preposition $\dot{\varepsilon} v(A, E, G, H$, $S^{2}, Y, \Gamma, \Psi, 565,788$, Byz) or before each of these words $(B, \Theta)$. Better but not so numerous manuscripts are the evidence for the second teaching given without articles $\mathrm{N}, \mathrm{C}, \mathrm{D}, \mathrm{F}, \mathrm{K}, \mathrm{L}$, $\mathrm{M}, \mathrm{S}^{*}, \mathrm{U}, \Delta, \Pi, \Omega, 1,28,118,157,579,700,1241,1424,1582,2542,2358, f^{1}$.

15 Cf. H.B. Swete, The Gospel According to St. Mark., 281; W. Schmithals, Das Evangelium nach Markus, 535; J. Gnilka, Das Evangelium nach Markus, vol. 2, 159; D. Lührmann, Das Markusevangelium, 204; R. Pesch, Das Markusevangelium. II, 233; B.M.F. van Iersel, Marco. La lettura e la risposta. Un commento, 343; S. Légasse, Marco, 627; J.R. Edwards, The Gospel According to Mark, 368; R.T. France, The Gospel of Mark, 475 n. 51.

16 Cf. H. Langkammer, The Gospel According to St. Mark, 280: "For this purpose, Jesus indicates the manner of existence of angels in heaven, showing that people will be like them. Similar views were then expressed by Jewish apocalyptic literature and scribes. According to Hen Et 15: 7, angels were not given wives .... R. Bartnicki shares this view in Jezus $w$ drodze do śmierci i zmartwychwstania, 491: "The concept of the state of men and women after the resurrection, which Jesus pronounces in v. 25, without trying to prove it, is a radical transformation which makes them similar to 'the angels in heaven'. Thus, according to the beliefs of ancient Judaism, angels are spirits who do not try to eat or drink and who do not engage in sexual activity unless they go astray." This passage together with the commentary on this pericope depends on É. Trocmé, L'Évangile selon saint Marc, 306.

17 The overview of the history of interpretation of this fragment is presented in the latest monograph by J.J.T. Doedens, The Sons of God in Genesis 6:1-4.

18 The male sex of angels is implied by justifying the circumcision of Abraham's offspring in the Book of Jubilees, which is an extension of the canonical message: "Because the nature of all of the angels of the presence and all of the angels of sanctification was thus from the day of their creation. And in the presence of the angels of the presence and the angels of sanctification he sanctified Israel so that they might be with him and with his holy angels" (Jub 15: 27). In the Hellenistic romance of Joseph and Asenath (15:7-8), a heavenly being appears as the daughter of the Most High who is called Metavoia. The author adds that 
an oath and solemnly strengthening it with curses, they carry out their intention under the leadership of an angel named Semyaz. They do not only mate with the chosen women, but also teach them sorcery and incantations. The resultant offspring of this union are called "giants" (Enoch 6: 2-7:1).

A little further, the reader of this apocalypse learns that Enoch is to carry the verdict to the fallen angels. From the angels remaining in heaven, he receives a definite announcement that those who have left heaven, have taken women as wives and become corrupted, will not be forgiven (Enoch 12:4-5).

The punishment for yielding to desires typical of people by the fallen angels is confirmed in the third text. Their desire is shown to be contrary to the will of the Creator, because He has not foreseen a relationship with women for them (Enoch 14:24-15:7). The contrast between the plan of God and the betrayal by angels is emphasized at the very end of this passage:"Indeed you, formerly you were spiritual, [having] eternal life, and immortal in all the generations of the world. That is why [formerly] I did not make wives for you, for the dwelling of the spiritual beings of heaven is heaven" (Enoch 15:6-7). ${ }^{19}$

The Syriac Apocalypse of Baruch not only juxtaposes the will of God with the rebellion of angels, but also distinguishes those who have left heaven to mate with women and the innumerable majority of angels who refrained from these sexual relations: "And some of them came down and mingled themselves with women. At that time they who acted like this were tormented in chains. But the rest of the multitude of angels, who have no number, restrained themselves"(2 Bar 56: 12-14).

The two main interpretations which dominate in the exegesis of Jesus' words about the resurrected and their resemblance to angels are not satisfying. The first one does not define this similarity in detail and is limited to quoting the texts which speak about unidentified features common to people in the world to come and angels. The other interpretation, which also refers to similarities in the documents of Judaism, indicates a concrete tertium comparationis, which the celibacy of the resurrected and the angels would be. However, the text of the Gospel does not allow such a reduction in comparison between the resurrected and the angels both on the philological-logical and on the literary-theological levels.

because of her virtues she enjoys respect among all angels. His observation suggests that he distinguishes her from other angels.

19 This and next translation, see n. 10. 


\section{The relationship between the announcement of celibacy and the comparison with angels}

Two clauses - the statement about the celibacy of the resurrected and their comparison to the angles are linked with the conjunction $\dot{\alpha} \lambda \lambda \lambda^{\alpha}$. The majority of translations into modern languages use the conjunction "but". ${ }^{20}$ However, even in the commentaries with the conjunction "but" the comparison with angels is interpreted as a sentence which provides details or justifies the announcement of the celibacy of the resurrected. In other words, two clauses with this conjunction are frequently interpreted as if the conjuction "since" ( $\gamma$ á $\rho$ ) or "because" (ö $\tau$ ) was used. Such an interpretation is provided by the influential commentary to the Gosepl according to St. Mark: "The Markan Jesus provides no biblical justification for this assertion that the resurrected saints will not marry because they will become like angels." ${ }^{21}$ New Living Translation also refers the comparison of the resurrected to the angles to the celibacy of both groups: "For when the dead rise, they will neither marry nor be given in marriage. In this respect they will be like the angels in heaven".

When the conjunction $\dot{\alpha} \lambda \lambda \dot{\alpha}$ combines two clauses, then the one linked with this conjunction is not subordinate to the first or does not have a justifying or explanatory function of the content contained in the first clause. A few examples from the Gospel of Mark and from other Gospels may shed some light on the significance of the relationship between these kinds of coordinate clauses. The criterion for their choice is also the possibility of interpreting the relation between them in a limited sense of explanation or justification of the first sentence by the second.

A construction similar to the syntax of the sentence connecting the celibacy of the resurrected with their comparison to the angels has already occurred once in the Gospel of Mark. In the King James Version translation, it is rendered in the following way: "Then He went up into the boat to them, and the wind ceased. And they were greatly amazed in themselves beyond measure, and marveled. For ( $\gamma \alpha \dot{\rho} \rho)$ they had not understood about the loaves, because

20 The meaning is not rendered in New International Version, New International Reader's Version.

21 J. Marcus, Mark 8-16, 828. Whereas in the translation of the Gospel used in this commentary the Greek conjunction à $\lambda \lambda$ á is translated precisely as "but", and not as "because". 
( $\dot{\alpha} \lambda \lambda \alpha$ ) their heart was hardened" (Mark 6:51-52). ${ }^{22}$ In this way, the sequence of the last two subordinate sentences indicates two further reasons: the amazement of the disciples results from their lack of understanding, and their lack of understanding from the hardened hearts. However, the Greek text only refers to one, though double, reason for the amazement of the disciples. The conjunctions are used correctly in the New Revised Standard Version: "Then he got into the boat with them and the wind ceased. And they were utterly astounded, for ( $\gamma \alpha \dot{\rho} \rho)$ they did not understand about the loaves, but (å $\lambda \lambda \dot{\alpha})$ their hearts were hardened." The amazement of the disciples is explained by a single coordinate clause, which emphasizes their deficiencies; on the one hand, it is the insufficient understanding, and on the other, hardness of their hearts. In other words, the negative state of the heart of the disciples is not so much explained (their lack of understanding due to the dullness of their hearts), but emphasized by the opposition of two sentences connected by the conjunction $\dot{\alpha} \lambda \lambda \dot{\alpha}$. The sentence attached by this conjunction indicates not so much the cause of this lack of understanding but something that is more profound and fundamental: the state of their inmost part.

Furthermore, in other compound coordinate sentences, in which the first clause contains negation and the other is attached by means of the conjunction $\dot{\alpha} \lambda \lambda \dot{\alpha}$, the part which is negated in the first clause is only a certain aspect of reality which is more strongly and fully marked by the second positive sentence. This logical relation based on an analogical syntactic structure is also illustrated by other examples outside the Gospel of Mark:

1) The conjunction does not introduce to the clause which barely/only explains the fact of stopping near the village: "Now Jesus had not yet come to the village, but (á̉ $\lambda \lambda \dot{\alpha})$ was still at the place where Martha had met him" (J 11:30). The clause introduced by the conjunction emphasizes that Jesus is all the time in the same place and Mary goes there to meet $\operatorname{Him}(\mathrm{J}$ 11:32).

2) In the next example, the clause introduced by the conjunction characterizes the attitude of every believer in Christ to his/her possessions: "Now the whole group of those who believed were of one heart and soul, and no one claimed private ownership of any possessions, but ( $\dot{\alpha} \lambda \lambda \dot{\alpha})$ everything they owned was held in common" (Acts 4:32). The clause after the conjunction stresses the fact of the common ownership of goods and not only indicates the reason for using particular vocabulary.

22 The conjunction "for" instead of "but" appears in: Douay-Rheims Bible, Darby Bible Translation, Webster's Bible Translation, Young's Literal Translation. 
3) Similarly, this example does not stress only the reason for the situation presented in the negative clause "So then you are no longer strangers and aliens, but (à $\lambda \lambda \alpha$ á) you are citizens with the saints and also members of the household of God" (Eph 2:19). The clause after the conjunction reveals the positive dignity of Christians, the attitude, which is explained in the next verse.

In each of the three examples, which are analogical to Markan text - both in the commentary of the narrator about the reason for the amazement of disciples during the lake crossing and in the answer of Jesus given to the Sadducees - the content expressed in the clause introduced by the conjunction "but" is more significant than the negative sentence that precedes this conjunction. In the first text, the narrator pays attention to Jesus' staying in the same place (conversations first with Marta and then with Maria). In the second text, Luke emphasizes the fact of a community of goods of the first followers of Jesus in Jerusalem. The third one the new dignity of Christians is emphasized, which is presented as a special belonging to the community of saints and to God.

In the interpretation of these and other similar compound coordinate sentences, the meaning of the second clause should not be reduced to the function of explaining or justifying the content signified by the first clause. Thus, the answer of Jesus to the question of Pharisees is not the assertion of the celibacy of the resurrected, which would be justified by their comparison to the angels. His answer, however, highlights their new state, in which they will not only get married, but also will be like the angels in heaven. What exactly is this similarity based on?

The comparison with the particle used in the function of the conjunction "how" ( $\dot{\omega} \varsigma)$ can be found in two key texts for the theology of the Gospel of Mark. The comparisons created by these particles are subject to divergent explanations. ${ }^{23}$

After baptism, Jesus sees "the Spirit descending on him like a dove" (Mark 1:10). The metaphor of a dove refers to the descent of the Spirit and has a strictly defined meaning in the narrative. The Spirit does not descend into the water, it does not float above it as in the description of creation (Gen 1:2), it does not touch it to sanctify it. During the baptism of Jesus, the Holy Spirit does not outpour, does not overpower many people, but descends in His direction, towards Him, and even on Him. Such detailed specification of the purpose of the descent of the Spirit has a determining significance not only for a precise indication of the addressee of the declaration of the voice from heaven. Jesus'

23 Cf. A. Malina, Gli scribi nel Vangelo di Marco, 63-64; idem, Chrzest Jezusa w czterech Ewangeliach, 119-122. 
vision of the descent of the Spirit makes Him the only addressee of the words of the voice coming from heaven.

In contrast to the first mention, the comparison of Jesus' teaching with the activity of the scribes serves to indicate some difference between them (Mark 1:22). By analogy with the first mention, the difference here is not absolute, as in the case of the Spirit and the dove where the similarity was not complete. The reason for the astonishment of Jesus' listeners is that he does not resemble other teachers. The public role of teachers - Jesus and scribes - is what unites them and makes it possible to compare their teaching, which is tertium comparationis. However, the difference between them and Jesus is that Jesus possesses some authority that the scribes do not have. ${ }^{24}$

Similarly, in the case of the comparison between the resurrected and the angels, similarity has a well-defined range by the use of the prepositional phrase

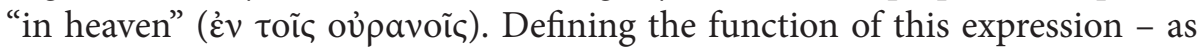
a prepositional phrase (defining angels) or as an adverbial of location (denoting the place where the resurrected reside) - depends primarily on the meaning of the noun itself. Although the word "heaven" (oujpavóc) in the Bible is an ambiguous term, in the Gospel of Mark, the basic differences of meanings are closely related to the grammatical forms of this noun. ${ }^{25}$ It appears seventeen times in the text (without Mark 16:19): five times in the singular from and without an article, seven times in the singular from and with an article and five times in the plural form and always with an article.

In the singular from and without an article, the noun "heaven" (oủpavóc) defines the extraterrestrial reality, which in all five cases is compared to what is human and temporal: "treasure in heaven" is opposed to material goods (Mark 10:21); the origin of the baptism of John "from heaven" excludes its "human origin" (11:30,31); "The ends of the earth" and 'the ends of the heavens" are the boundaries where the chosen ones come from (13:27); the exclusion from the knowledge of the final time of the "angels in heaven" is a higher degree in the face of the lack of knowledge of "no one [on earth]" (13:32).

24 The Evangelist does not explain whether this difference originates from the lack of any power in the activity of the scribes, or whether it is the result of their other authority, for example reduced or dependent on another subject. The summary shows only that the scribes do not have the power which characterizes the teaching of Jesus. The lack of details, however, does not imply the general nature of the comparison, but corresponds to its main function and the corresponding function of its position at the beginning of the narrative about the public activity of Jesus.

25 Pace S. Légasse, Marco, 74, footnote 10: „Marco usa ouranos talvolta al singolare [...], talvolta al plurale semitizzante [...] indiferrentemente per designare o la dimora divina o il cielo cosmogonico". 
In the singular form and with the article, the term "heaven" (ó oủpavóc) denotes the vault above the earth, the material space distinguished from the surface inhabited by people: birds [from] the sky (Mark 4:32); the direction of Jesus' look (6:41, 7:34); the origin of visible sign (8:11); place of stars (13:25); part of the creation which will pass away (13:31); clouds [from] the sky (14:62).

In the third group, the term "heaven" (oi oujpavoi) in the plural form and with the article - has a metaphorical meaning in the absolute sense; it denotes what is supernatural, God's dwelling: (Mark 1:10,11; 11:25; 12:25; 13:25). In the last text the noun appears twice and has two different meanings. First, it de-

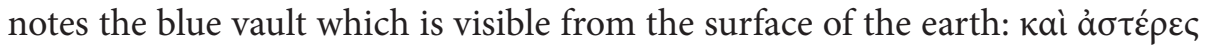

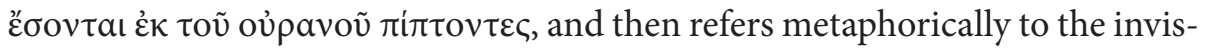

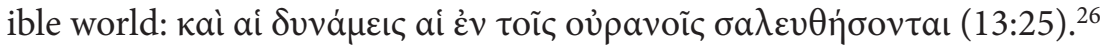

The announcement that all resurrected people will be "like the angels in heaven" is not tantamount to comparing their future existence to the celibacy of spiritual beings, but defines their place of being which is heaven - the space currently occupied by angels - free from tasks (fertility understood as ruling/power), which the Creator entrusted to people on earth.

In other words, the tertium comparationis in the comparison between the resurrected and the angels is not their celibacy, but dwelling of both of them in heaven as the dwelling place of God. The life to come of the resurrected in heaven cannot be reduced to the present life on earth, therefore it is a mistake to judge the existence of the resurrected according to earthly categories. In any case, the aim of Jesus' answer is to show the significance of the relationship with God and cannot be restricted to the limits formulated by the question of His opponents. This sense is confirmed by the continuation of His response.

\section{God as a giver of life}

In the second part of his answer Jesus shows the Sadducees that they do not know the text (a rhetorical question "Have you not read ...?") (Mark 12:26), which presents the revelation of God to Moses in the burning bush (Ex 3:1 4:17).The fact that Jesus reminds of His personal relationship to the three pa-

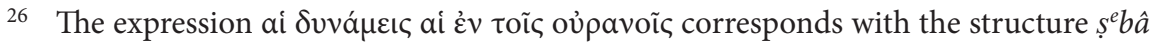
haššâmajîm in the Hebrew Bible, which denotes deities or angels competitive to the God of Israel or subordinated to Him (2 Kings $17: 16$; $23 ; 4$; Isa 34,4; Jer 8:2; Da 8:10, etc.). In the New Testament, apart from the synoptic Gospels, it appears in (Matt 24:29-30; Luke 21:26) and signifies beings in the celestial hierarchy ultimately subordinated to God (1 Cor 15:24; 1 P 3:22). Cf. J. Mateos, F. Camacho, Il Vangelo di Marco, vol. 1, 86. 
triarchs is particularly justified in the context of the discussion with the Sadducees about the resurrection as they question the doctrine on this subject by referring to the institution of the levirate, which stresses the procreative purpose of marriage.

Jesus quotes a text from the Torah, not only because His interlocutors recognize it as the word of God. He chooses it because of their reference to marriage. The patriarchs mentioned in the text had great difficulties with offspring as they either did not have it for a long time (Abraham, Isaac, Jacob's wives), or their sons were in conflict with each other and their lives were threatened (Isaac, Jacob and his twelve sons).

Divine Providence extends not only to the promise of offspring, but also guarantees its survival and multiplication, as well as eternal life. Jesus interprets God's descriptions in such a way that the Sadducees cannot oppose this explanation: revealing Himself to Moses as the God of the patriarchs who died long ago, as well as the God of the living, not of the dead (the latter part is the original element in the Old Testament text), He appears at the same time as the One who raises the dead. The ongoing interpersonal relationship between God and people is a guarantee of their eternal life, which ensures resurrection as a work of God's power.

\section{Bibliography}

The Apostolic Fathers. v. 2: The Shepherd of Hermas. The Martyrdom of Polycarp. The Epistle to Diognetus, trans. K. Lake, London-New York 1917.

Asher J.R., Polarity and Change in 1 Corinthians 15: A Study of Metaphysics, Rhetoric, and Resurrection, Tübinen 2000.

Bartnicki R., Jezus $w$ drodze do śmierci i zmartwychwstania. Komentarz do Ewangelii Marka 8,27-16,20. Część I: Mk 8,27-13,37, Warszawa 2018.

Bock D., Mark, Cambridge 2015.

Boring M.E., Mark. A Commentary, Louisville-London 2006.

The Dead Sea Scrolls Translated, trans. F.G. Martínez, Leiden 1994.

Doedens J.J.T., The Sons of God in Genesis 6:1-4. Analysis and History of Exegesis, Leiden 2019.

Dschulnigg P., Das Markusevangelium, Stuttgart 2007.

Edwards J.R., The Gospel According to Mark, Grand Rapids 2002.

France R.T., The Gospel of Mark. A Commentary on the Greek Text, Grand Rapids 2002. Gnilka J., Das Evangelium nach Markus, vol. 2: 8,27-16,20, Leipzig 1980.

Grasso S., Vangelo di Marco. Nuova versione, introduzione e commento, Milano 2003.

Gundry R.H., Mark. A Commentary on His Apology for the Cross, Grand Rapids 1993. 
Haenchen E., Der Weg Jesu. Eine Erklärung des Markusevangeliums und der kanonischen Parallelen, Berlin 1966.

Iersel B.M.F. van, Marco. La lettura e la risposta. Un commento, Brescia 2000.

Kiel Y., Sexuality in the Babylonian Talmud. Christian and Sasanian Contexts in Late Antiquity, New York 2016.

Langkammer H., Ewangelia według św. Marka. Wstęp - przekład z oryginału - komentarz, Poznań-Warszawa 1977.

Légasse S., Marco, Roma 2000.

Lohmeyer E., Das Evangelium des Markus, Göttingen $1963^{16}$.

Lührmann D., Das Markusevangelium, Tübingen 1987.

Malina A., Chrzest Jezusa w czterech Ewangeliach. Studium narracji i teologii, Katowice 2007.

Malina A., Gli scribi nel Vangelo di Marco. Studio del loro ruolo nella sua narrazione e teologia, Katowice 2002.

Marcus J., Mark 8-16. A New Translation with Introduction and Commentary, New Haven-London 2009.

Mateos J., Camacho F., Il Vangelo di Marco, vol. 1: Analisi linguistica e commento esegetico, Assisi 1997.

The Old Testament Pseudoepigrapha, vol. 1-2, red. J.H. Charlesworth, New York 19831985.

Perego G., Vangelo secondo Marco. Introduzione, traduzione e commento, Cinisello Balsamo 2011.

Pesch R., Das Markusevangelium. II. Teil. Einleitung und Kommentar zu Kap. 8,27-16,20, Freiburg-Basel-Wien 19914.

Schmithals W., Das Evangelium nach Markus. Kapitel 9,2 - 16,18 (sic!), Gütersloh 1979.

Standaert B., Marco. Vangelo di una notte, vangelo per la vita. Commentario, Bologna 2012.

Swete H.B., The Gospel According to St. Mark. The Greek Text with Introduction, Notes and Indices, London $1908^{2}$.

Taylor V., The Gospel According to St. Mark, London $1966^{2}$.

Trocmé É., L'Évangile selon saint Marc, Genève 2000.

Wróbel M., "Faryzeusze i saduceusze wobec zmartwychwstania," Verbum Vitae 8 no 15 (2009) 143-154. 